\title{
THE FALL OF MAN IN SHAKESPEARE'S MACBETH COMPARING TO THAT IN A CREATION STORY: A STUDY FROM QUR'ANIC PERSPECTIVE
}

\author{
SANAA' SA'EED MIRZA \\ Dept. of English, College Of Languages, University of Duhok, Kurdistan Region-Iraq
}

(Received: March 2, 2020; Accepted for Publication: September 19, 2020)

\begin{abstract}
ABSRACT
Inspired and motivated by our conviction that "Shakespeare is a gift of Heaven to all of Mankind, for every creed, in every age" (Lings, 1998, 12), this research aims at studying William Shakespeare's Macbeth from a Qur'anic perspective instead of a biblical one, as has usually been done so far. The study utilizes Islamic pedagogy to examine Macbeth, a European masterpiece, hypothesizing that Islam offers a uniquely different view of the world from that of the European one. For its textual analysis, the study relies on verses translated from the Noble Qur'an as well as Hadiths (the prophet's traditions) from Sunnah, in addition to the text of Macbeth. The axiomatic question that is raised here is whether or not we have the right to categorize Shakespeare's Macbeth into "sacred art". The study answers positively to this question since the thematic framework of the play revolves around "the essence of religion" (Lings, 1998, 12).

The study attempts to analyze and compare the fall of man in Shakespeare's Macbeth to that in the story of man's creation from Qur'anic perspective according to five axes. The first axis is about the temptation of the evil power in both stories, Adam's creation in Quran and Shakespeare's Macbeth. The second axis examines the role of Hawaa (Eve) and Lady Macbeth as temptresses. The third axis is about the feeling of remorse for the evil actions that they take and the punishment of God. The fourth axis presents a study of the nature of some encounters between humanity and evil forces. The fifth axis presents a brief study of the types of human soul (Nafs) from Quranic perspective to diagnose the role of the soul in determining the characteristics of each personality.

Yet, the study concludes that Shakespeare presents Macbeth with a narrow perspective to represent only the inherent weakness of humanity in the face of evil forces, ignoring his charitable nature to encounter evil forces, and his fall is cursed eternally because of his insistence on evil; while Adam (peace be upon him) represents humanity in all of his conditions, and his fall is not eternal because of his remorse and repentance.
\end{abstract}

KEY WORDS: Sacred art, Qur'anic perspective, temptresses, Islamic pedagogy, essence of religion

\section{LITERATURE REVIEW}

$\mathbf{T}$ he history of the battle between humanity and the evil force dates back to the first moment of the creation of Adam (peace be upon him) when Satan (devil) rejects the command of God [Allah] Almighty to prostrate before Adam. From that eventful moment, Satan and his forces tried relentlessly to seduce humans to plunge them into sin. The battlefield of this eternal war is in human's soul and mind. It is a psychological battle in which the evil forces use all means and appear in different forms to take advantage from a moment of human's weakness to obliterate him into the mire of sin more and more. God warns mankind against devil and his satanic forces in different situations in Quran. He illustrates the real nature of devil and his various satanic ways of temptation, offering at the same time guidance to get rid of it.

In Qur'an, the story of Adam's creation is traced in many places, such as; Surah' Al-Kahif, Surah' Sād, and Surah' Yassin, but it is remarkably explained in Surah' Al-Baqarah when God [Allah] tells the angels, "Indeed, I will make upon the earth a successive authority." They said, "Will You place upon it one who causes corruption therein and sheds blood, while we declare Your praise and sanctify You?" Allah 
said, "Indeed, I know that which you do not know." (The Noble Qur'n, 2016, 2: 30).

In such a way, the story of Adam (the first Mankind) begins. God creates Adam from a handful of soil which is taken from different places of earth; (mountains, valleys, infertile deserts, and fertile plains) contained all metals and natural elements of earth. It is destined for Adam's descendants to be as varied as the soil from which they are created, and have different qualities and appearances according to the land they are created from. The evidence for this is the Hadith of the prophet, Mohammed [peace be upon him], when he says: "Indeed Allah Most High created Adam from a handful that He took from all of the earth. So the children of Adam come in according with the earth, some of them come red, and white and black, and between that, and the thin, the thick, the filthy, and the clean."(Jami at-Tirmidhi: Chapters on Tafsir, Hadith Sahih, 1978: 2955).

God Almighty refers to the handful of soil with various names, in different places in Quran, according to the different stages that the creation of Adam undergoes. For example; God Almighty refers to the soil, in Surah' Ali 'Imran, as a dust when He says "Indeed, the example of Jesus to Allah is like that of Adam. He created Him from [Soil] dust; then He said to him, "Be," and he was" (The Noble Qur'an, 2016, 3: 59), as a clay in both Surah Al- Hijr and Surah' Sad when God says "And We did certainly create man out of clay from an altered black mud." (The Noble Qur'an,2016,15: 26), and "when your Lord said to the angels, "Indeed, I am going to create a human being from clay" (The Noble Qur'an,2016, 38: 71). Also, it is referred as a sticky clay or mud in Surah' As-Saffat when God says "Are they a stronger [or more difficult] creation or those [others] We have created?" Indeed, We created men from sticky clay."'(The Noble Qur'an,2016, 37: 11), and as a potter's clay in Surah' Ar-Rahman when God says 'He created man from clay like [that of] pottery (The Noble Qur'an,2016, 55: 14).

Then God honors Adam and blows His soul into him. He teaches him the knowledge then commands the angels to prostrate before him "And $\mathrm{He}$ taught Adam the names - all of them. Then He showed them to the angels and said, "Inform Me of the names of these, if you are truthful. They said, "Exalted are You; we have no knowledge except what You have taught us. Indeed, it is You who is the Knowing, the Wise. He said, "O Adam, inform them of their names."
And when he had informed them of their names, He said, "Did I not tell you that I know the unseen [aspects] of the heavens and the earth? And I know what you reveal and what you have concealed. And [mention] when We said to the angels, "Prostrate before Adam"; so they prostrated, except for Iblees (Satan)". (The Noble Qur'an,2016, 2: 31-33).

When God commands the angels to prostrate before Adam, they all do immediately except Satan, who arrogantly refuses to obey the order and argues that he is better than Adam since God creates him from fire, whereas creates Adam from clay. Satan is a creature from the Jinn world which is different from both angels and mankind. Since he was the righteous among the Jinn, he was elevated to a lofty position among angels. Therefore, God [Allah] asks him, "What prevented you from prostrating when I commanded you?" [Satan] said, "I am better than him. You created me from fire and created him from clay." (The Noble Qur'an,2016,7: 12). Satan's pride leads him to ignore the fact that God creates Adam with his hands and blows into him from His soul, "And when I have proportioned him and breathed into him of My [created] soul, then fall down to him in prostration." (The Noble Qur'an,2016, 15: 29). Satan disobeys God's command therefore, God expels him from Eden and curses him until the Day of Resurrection, "[Allah] said, "Then get out of it, for indeed, you are expelled. And indeed, upon you is the curse until the Day of Recompense."(The Noble Qur'an,2016,15: 3435). Satan prays and asks God to reprieve him until the Day of Judgment. After God accepts his prayer, Satan promises to tempt the children of Adam, except the faithful servants of God, over whom he has no power. "He said, "My Lord, then reprieve me until the Day they are resurrected. "[Allah] said, "So indeed, you are of those reprieved. Until the Day of the time wellknown. "[Iblees][Satan] said, "My Lord, because You have put me in error, I will surely make [disobedience] attractive to them on earth, and I will mislead them all. Except, among them, Your chosen servants." (The Noble Qur'an,2016, 15: 36-40). God asserts that Satan has no authority over his servants except those who are gone astray, "Indeed, My servants - no authority will you have over them, except those who follow you of the deviators." (The Noble Qur'an,2016, 15: 42).

So, if a man is sincere in his relationship with God seeking for His satisfaction and His 
protection from the evil of Satan, he will be safe, but if he chooses the wrong path, he will be deviated from the humanity and become an easy prey to the satanic forces of evil.

On the other hand, the story of this perpetual encounter which is mentioned in both the Old and New Testaments, yet different in some details to that in the Quran becomes one of the most universal themes in literature. For example; Golding, in his novels Lord of the Flies and the Spire, Thomas Hardy in Tess of the d'Urbervilles, Lawrence in Sons and Lovers, Shelley in The Revolt of Islam use the image of the Garden of Eden. In Paradise Lost, John Milton opens his epic formally with the first disobedience of mankind toward God and his fall from Eden (Paradise). In Doctor Faustus, Christopher Marlowe explores the role of Mephistopheles (devil) to deceive and tempt Dr. Faustus and later leads him to his downfall. In most of his plays, Shakespeare presents various forms of evil. For Samuel Johnson, Shakespeare's plays are "just representation of general nature", and his characters are "the genuine progeny of common humanity" (1962, p.2725), they are "sentiments of real life" (1962, p.2726) and "human sentiments in human language" (1962, P.2727). Samuel Johnson asserts that the "reflection that strikes the heart is not that the evils before us are real evils, but that they are evils to which we ourselves may be exposed" (1962, p.2731). In Macbeth, the focus of our current study, Shakespeare shows us his perception of evil remarkably in his character Macbeth and his relationship with the forces of evil (the three witches) who try to tempt him. Many critics see that Macbeth represents humankind. About Shakespeare's Macbeth, Jean E. Howard states that "[Macbeth] is the last of great Shakespearean tragedies that examine the dimensions of spiritual evil... As a culmination of a series of tragedies on evil, the play offers an intensely human study of the psychological effects of evil on a particular man and, to a lesser extent, on his wife." (2003, p.1255). For her, Macbeth as a character is "presented to us as typically human, both in his understanding and in his perverse ambition... a perspective on the operation of evil in human affairs" (2003, p.1257). In Macbeth and the Metaphysic of Evil, Knight says that "Macbeth is Shakespeare's most profound and mature vision of evil ... the central human theme... one is in touch with absolute evil, which, being absolute, has a satanic beauty, a hideous, serpent-like grace and attraction, drawing, paralyzing" (2001, p.160). In Shakespeare the Invention of the Human, Bloom asserts that the "universal reaction to Macbeth" is that "we identify with him" and Shakespeare rather dreadfully sees to it that we are Macbeth;" (1999, p.517). For him "the dreadful is about to happen, and that we have no choice but to participate in it" $(1999,535)$. He adds that we "are to journey inward to Macbeth's heart of darkness, and there we will find ourselves more truly and more strange.."(1999, 518).

In the current study, we try to analyze the fall of man in Shakespeare's Macbeth comparing to that in a creation story from Qur'anic perspective to see whether Macbeth as a character represents the humanity in his face to evil force and whether he really has no choice but to submit to the forces of evil.

\section{FIRST AXIS: THE TEMPTATION OF EVIL POWER IN BOTH QURAN AND SHAKESPEARE'S MACBETH}

Temptation is a powerful vision of evil that turns the hearts of the characters to seek for their own selfish desires. In Quran, temptation is clearly seen in Satan's false promise to Adam to turn his heart to look for his own desire (seeking immortality in paradise), and brings nothing but his fall from Eden.

Adam and his wife Eve (Hawaa) are accepted to live in paradise and to enjoy and eat from its fruits wherever they wish except one tree, they are forbidden to approach it, as the Quranic verse states, "And We said, "O Adam, dwell, you and your wife, in Paradise and eat therefrom in [ease and] abundance from wherever you will. But do not approach this tree, lest you be among the wrongdoers."(The Noble Qur'an, 2: 35). But Satan decides to tempt them by whispering and pouring his poisonous words into Adam and Eve' ears. Adam and Eve resist Satan's temptations for a long time. But Satan does not despair and continues his attempts day after day, saying to Adam and Eve that they will be immortal in paradise if they taste the forbidden fruit claiming that God has prevented them from that tree to be neither angels nor immortal in Paradise, swearing that he is their own sincere advisor, as the verses say in Surah Al- A'raf “--He said, "Your Lord did not forbid you this tree except that you become angels or become of the immortal." "And he swore [by Allah ] to them, "Indeed, I am to you from among the sincere 
advisors."(The Noble Qur'an,7: 20- 21). The whispering of Satan is dangerous, as it always is since it is false, and at the same time plausible. Adam, with his common sense does not believe that there is someone who dares to swear by God falsely. Adam, however, is a human being with weaknesses such as; forgetfulness, weak determination, and volatile heart. Satan takes advantage of Adam's weaknesses and exploits his humanity and his psychological condition to get him into sin. Forgetting God's command, Adam and Eve believe Satan's false promise of immortality and taste the fruit of the forbidden tree, but then they see that "their private parts became apparent to them, and they began to fasten together over themselves from the leaves of Paradise.'(The Noble Qur'an,7:22).

Although temporarily Satan wins the first encounter, he cannot take Adam totally away from the obedience of God. Therefore God calls them (Adam and Eve),"Did I not forbid you from that tree and tell you that Satan is to you a clear enemy?" "They said, "Our Lord, we have wronged ourselves, and if You do not forgive us and have mercy upon us, we will surely be among the losers." "[ Allah ] said, "Descend, being to one another enemies. And for you on the earth is a place of settlement and enjoyment for a time."(The Noble Qur'an, 7: 22-24).

Adam realizes that he has been deceived by Satan's false promise and temptation. Adam realizes that Satan is his eternal enemy and will not be his advisor, therefore he immediately succumbs to the command of God and repents fervently, begging God's Forgiveness. God compassionately accepts Adam's repentance and gives him the chance to make good as atonement for his sin, as God says "Then Adam received from his Lord [some] words, and He accepted his repentance. Indeed, it is $\mathrm{He}$ who is the Accepting of repentance, the Merciful."'(The Noble Qur'an, 2: 37). Despite of his fall from Eden, Adam does not be away from God. The guidance comes from God to reassure Adam and his descendants that "whoever follows My guidance - there will be no fear concerning them, nor will they grieve", "And those who disbelieve and deny Our signs - those will be companions of the Fire; they will abide therein eternally."(The Noble Qur'an, 2:38-39). God reveals the reason behind Adam's temporary inability to encounter satanic temptation declaring his weaknesses (forgetfulness and inaction), "And We had already taken a promise from Adam before, but he forgot; and We found not in him determination"'(The Noble Qur'an,20: 115). This verse justifies the inability of human to maintain the purity of his soul continuously and because of the inherent weakness, humanity may temporarily falter. Herein lies the inevitable need for the divine principle in such difficult situations.

Although Satan, with his false promise and ornamented words, is behind Adam's expulsion from Paradise, his battle does not end until he falls as many of Adam's children as possible in the mire of sin, "[Iblees] said, "By your might, I will surely mislead them all/ Except, among them, Your chosen servants."(The Noble Qur'an, 38: 82-83). Therefore, God warns Adam's children of Satan's tricky methods of temptation, when he says "O children of Adam, let not Satan tempt you as he removed your parents from Paradise, stripping them of their clothing to show them their private parts. Indeed, he sees you, he and his tribe, from where you do not see them. Indeed, We have made the devils allies to those who do not believe" (The Noble Qur'an, 7: 27).

Satan's battle against Adam and his children is psychological warfare, in which he uses his "voice", and his "horses and foot soldier" and becomes "a partner in their wealth and their children" and "promise them" with "delusion" (The Noble Qur'an, 17: 64).

Mankind should understand these types of deceptive satanic methods, to differentiate the wrong way of devil from the way of salvation; for God has made both ways clear, "Did I not enjoin upon you, $\mathrm{O}$ children of Adam, that you not worship Satan - [for] indeed, he is to you a clear enemy" (The Noble Qur'an, 36: 60). In the same vein, Prophet Ibrahim advises his father not to worship Satan, since "Satan has ever been, to the Most Merciful, disobedient" "O my father, indeed I fear that there will touch you a punishment from the Most Merciful so you would be to Satan a companion [in Hellfire]."( The Noble Qur'an, 19: 44-45). So, "It has been decreed for every devil that whoever turns to him - he will misguide him and will lead him to the punishment of the Blaze" (The Noble Qur'an, 22: 4).

In Hadith, Prophet Mohammed says "the Shaitan [Satan] sits in the paths of the son of Adam. He sits waiting for him, in the path to Islam, and he says: Will you accept Islam, and leave your religion, and the religion of your forefathers?", "Then he sits waiting for him, on the path to emigration, and he says: Will you 
emigrate and leave behind your land and sky?", "Then he sits, waiting for him, on the path to Jihad, and he says: Will you fight in Jihad when it will cost you your life and your wealth? You will fight and be killed, and your wife will remarry, and your wealth will be divided"(English Translation of Sunan AnNasa' $i$, 2007, Hadith 3136: p.40). This Hadith indicates the deceptive methods that Satan follows to tempt the children of Adam to make them disbelievers, as God explains in His saying "O you who have believed, enter into Islam completely [and perfectly] and do not follow the footsteps of Satan. Indeed, he is to you a clear enemy" (The Nobel Qur'an, 2: 208).

In Macbeth, Shakespeare opens his play with a powerful and mysterious vision of evil which is personified in the figures of three supernatural witches. Shakespeare links their appearance with the bad atmosphere (thunder and lightning) and bloody circumstances (war, treason, and killing) to reflect the evil and mysterious forces that accompany these witches.

In the same vein, Keith Thomas asserts in his book Religion and the Decline of Magic that the three witches represent Satan's agent and they are responsible for "thunder and lightning," that accompany their appearance (1971: 34). For Thomas, Satan is "God's grand cosmic antagonist. He was an omnipresent force, ever ready to prey upon man's weaker instincts and to tempt him away in paths of evil... To help him in his task he had an army of demons and evil spirits" (1971:557).

In Shakespeare's Macbeth, the first appearance of the three witches create an evil image in reader's mind, especially when they react brutally toward a sailor and his wife who offends one of them. By alluring words, the three witches change the personality of Macbeth, and bring nothing but his destruction. They use short rhyming verses, full of dark spells and riddles, in which the separation between the truth and falsehood is difficult because of the contradictory and paradoxical statements that they use such as; "[W]hen the battle is lost and won" and "[F]air is foul and foul is fair".

For Banquo, the three witches are "[t]he instruments of darkness" that they '---look not like th' inhabitants o' the earth". Their strange appearance makes Banquo at first to be unable to decide whether they are human or not. (Shakespeare's Macbeth, 1958, 1.3.125,40-46). In the same scene, Macbeth remarks that they "seem'd corporal [physical]" and yet they "melt[ed] / As breath into the wind" (Shakespeare, 1958, 1.3. 81-82). By the following prophecies, "Thane of Glamis", "Thane of Cawdor", and "king hereafter"(Shakespeare, 1.3.48-50), the three witches water Macbeth's wild desire for power and throne to grow, deriving him to many crimes and finally to his destruction.

Macbeth starts to experience the psychological conflict between his ambition to be a king and his moral human impulse when the king's messenger enters to greet him as the 'Thane of Cawdor'(Shakespeare,1.3.106). For Macbeth, the prophecy of three witches "Cannot be ill" (Shakespeare, 1.3.133), but quickly his moral human impulse protests that it "cannot be good' either (Shakespeare, 1.3.133). Yet, Macbeth decides with himself to leave everything to the Fate 'If Chance will have me king, why, Chance may crown me,/ Without my stir' (Shakespeare,1.3.144-145).

Temporarily, Macbeth's morality wins the first battle against the evil forces, but his resistance does not last long until he quickly falls prey to the attraction of the witches' words. His desire which is watered by witches' false words changes his personality that is "too full o' the milk of human kindness"( Shakespeare, 1.5.15), and stimulates him to commit many crimes and to dip himself more and more within the swamp of the sin.

Moreover, many horrible images are synchronized with the appearance of three witches to show their own evil power to bring chaos to Scotland and to nature for example; "Fair is foul, and foul is fair"'Shakespeare,1.1.10), "Stars, hide your fires!/ Let not light see my black and deep desires"(Shakespeare,1.4.50-51), "Nature seems dead, and wicked dreams abuse/ The curtained sleep"(Shakespeare,2. 1. 50-51), "earth,/ Hear not my steps, which way they walk"(Shakespeare, 2.1.56-57), "Macbeth does murder sleep"(Shakespeare,2.2. 35), "A falcon, towering in her pride of place,/ Was by a mousing owl hawk'd at and kill'd"( Shakespeare, 2.4.12-13), "And Duncan's horses--/ Turn'd wild in nature, broke their stalls, flung out"(Shakespeare, 2.4.14,16) and " they eat each other"'(Shakespeare, 2.4.19).

In the same vein, James VI asserts in his book, Daemonologie that the power of devil is not greater than the power of God, but it is dangerous and crooked, and "assaultes of Sathan are most certainly practized" (James, 1597: 2). 
On the other hand, Jane Jack says that "it is not merely human weakness that endangers the soul, but the direct attack of well-armed agents of Hell" (1955: 176). Macbeth not merely fell prey to his dark desire toward the throne, but also to the temptation of the agents of Hell by choosing to kill Duncan. Macbeth's weak faith in God and his inaction to resort to God to protect him from the assaults of evil forces endangers his soul.

Apparently, temptation in Macbeth is alluring and deceitful. It preys on Macbeth's mind, making him to believe that the prophecy of three witches is true and inevitable, and his speech "I have no spur/To prick the sides of my intent, but only/ Vaulting ambition" (Shakespeare, 1.7.2527) declares that he has already contemplated killing Duncan.

Another example to prove that temptation is deceitful is in the speech of the porter who names himself "Belzebub", and "porter of hellgate" (Shakespeare, 2.3. 2-3), when he describes the effect of alcohol and how it "provokes the desire, but it takes away the performance"(Shakespeare 2.3.24). His description serves metaphorically to indicate the similarity between the effect of temptation and alcohol because both make false promises. Just as alcohol "persuades him, and disheartens him; makes him stand to, and not stand to"(Shakespeare, 2.3.28-29), temptation stimulates a man to sin, but with false promise. And just as drink prevents the man from getting satisfied, sin prevents a man from obtaining rest and satisfaction. Therefore, when Macbeth kills Duncan, he feels that he will be satisfied but on the contrary, he feels that his mind is "full of scorpions"(3.2.36), and since "blood will have blood" (Shakespeare,3.4.122), Macbeth commits many other crimes just to get rest.

Macbeth, forgetting all the moral values, the sacred bonds of kinship, the chivalric principles, the universal principles of hospitality, the principles of the loyalty, the integrity of the king and kingdom, and the sacred bonds of friendship commits his great crime against the king, his close friend and many other innocent people. Macbeth does not stop at one crime but commits several crimes, and before each, he resorts to the witches and consults them. Although Macbeth calls them "black, and midnight hags" (4.1.48), he trusts them and believes their false promises since they say what satisfy his desire.

Unlike Macbeth, Banquo does not trust the agents of Hell since they "win us to our harm", and they "tell us truths,/Win us with honest trifles, to betray's / In deepest consequence"(Shakespeare, 1958,1.3.124,125127). Even when the witches try to tempt him with the alluring words, Banquo does not succumb to their temptation, leaving everything to God by standing "[i]n the great hand of God" (Shakespeare, 1958, 2.3.129).

In Macbeth, Shakespeare uses religious terminology to portray some of his characters like Malcolm, Macduff, and King Edward, as holy characters keeping their consciences clear, for example; Lenox refers to Macduff when he says, "Some holy Angel / Fly to the court of England" (Shakespeare, 1958,3.6.45-46), Malcolm depicts how King Edward "solicits Heaven" and has "a heavenly gift of prophecy," and "sundry blessings hang about his throne, / That speak him full of grace" (Shakespeare,4.3.149, 157-159), Macduff, comparing Malcolm to his father Duncan says "a most sainted king"( Shakespeare,4.3.109). These characters who do not grapple with temptation as Macbeth does stand against Macbeth to thwart the devil and be saint-like.

Concisely, satanic forces do not have absolute power to force mankind to commit a sin, but they nourish his internal desire to gain him.

\section{SECTION AXIS: THE ROLE OF EVE (HAWAA) AND LADY MACBETH AS TEMPTRESSES}

Entomologically, Hawaa is an Arabic form of Eve. It is derived from the word "hay" which means "living" (Stacey, 2008). Ibn Katheer says in his book The Beginning and the End that when Adam opens his eyes, he finds a beautiful face in front of him gazing at him. Adam is shocked and asks about the reason behind her creation, she says to ease his loneliness and bring him calmness. When the angels ask Adam about her name, he says that her name is Hawaa (Eve) which means "living" and she is so named because she is created from his (rib) (1990:74), as is also accepted by Christianity and Judaism.

In Quran, God says about the creation of Adam and Eve "O mankind, fear your Lord, who created you from one soul and created from it its mate and dispersed from both of them many men and women. And fear Allah, through whom you ask one another, and the wombs. Indeed, Allah is ever, over you, an Observer" (The Nobel Qur'an, 2016, 4:1).

The prophet Mohamed also refers to the creation of Adam and Eve, when he says "Treat 
women nicely, for a women is created from a rib, and the most curved portion of the rib is its upper portion, so, if you should try to straighten it, it will break, but if you leave it as it is, it will remain crooked. So treat women nicely."(Sahih Al-Bukhari: 3331).

Islam again agrees with Christianity and Judaism that Adam and Eve live in Eden and they are free to eat and delight of things therein. God gives His instruction and warns them not to approach one tree. The Quran does neither reveal the type of tree nor the location of Eden.

Adam and Eve obey God's order, but Satan who knows mankind's weakness and recognizes his nature waits to get a chance to fall Adam and his wife down. Satan, who is cunning and crafty in his means does not tell Adam and Eve directly to eat from the tree, but he whispers in their ears that their Lord "did not forbid you this tree except that you become angels or become of the immortal."(The Nobel Qur'an, 7:20). Years have passed and the alluring words of Satan revolved in Adam's mind as he desires to live in paradise forever, forgetting his promise to God that he will not approach the tree.

In the Old Testament, Genesis 3:1-7, the first temptation in the nature is happened when Satan disguises himself as a serpent and comes to Eve in the garden convincing her to eat the fruit from the forbidden (tree of good and evil). At the beginning, Eve refuses to obey the serpent (Satan), but then she obeys and gives some to Adam to eat. Adam and Eve become naked immediately and feel ashamed therefore, they try to hide themselves from God. In the same vein, a Christian minister William Branham says in his essay "The Original Sin" that "Eve was beguiled by the serpent. She was actually seduced by the serpent....He was so close to being human that his seed could, and did mingle with that of the woman and cause her to conceive. When this happened, God cursed the serpent" (2005). He adds that Satan (disguised serpent) "seduced her [Eve] and by her did Satan have a child vicariously. Cain bore the full spiritual characteristics of Satan and the animalistic (sensual, fleshly) characteristic of the serpent". Branham concludes that "Eve's sin is sexual in nature" rather than "being disobedience to God"(2005).

Quran differs totally from the Old and New Testaments, since there is no explicit verse confirming that Eve tempts Adam. In Quran, God refers to both (Adam and Eve) of being duped by Satan, dismissing together from Eden as a kind of punishment. Eating forbidden fruit is a sin committed by both, but Adam holds the responsibility because he is a prophet and God entrusts to him that Satan is his and his wife's enemy, "We said, "O Adam, indeed this is an enemy to you and to your wife. Then let him not remove you from Paradise so you would suffer"(The Nobel Qur'an, 20:117), "And We had already taken a promise from Adam before, but he forgot; and We found not in him determination" (The Nobel Qur'an, 20:115). AlTabari says in his interpretation that God means by saying (forget) that Adam has left His covenant (Muhammad ibn Jarir al-Tabari, 1994: 226).

But that does not mean Eve is innocent. It is mentioned in Al-Sunnah that Prophet Muhammad says "Were it not for Bani Israel, meat would not decay; and were it not for Eve, no woman would ever betray her husband", (Narrated by Abu Huraira in Sahih al-Bukhari: 3399). In explaining the Prophet's Hadith, Mohammed Saleh Al-Managed asserts in his essay The Story of Adam (Peace be upon him) that Imams agree that this Hadith refers to the story of the tree and how Satan tempts Eve to eat from it and how she leads Adam to partake. The word "betray" in Al-Hadith does not mean committing abominations but is a reference to how Eve follows her desire and listens to Satan's whisper. Eve's temptation to Adam is described as a betrayal (2019).

In the same vein, Ibn Katheer says in his book The Beginning and the End that it is Eve who eats from the tree before Adam, and she gives her husband to eat too, and God Knows (1990:78).

After they eat the fruit, immediately their private parts of body become apparent and they become ashamed. As a punishment, God banishes all of them from Eden and sends them to the Earth where Adam and Eve are forgiven after repenting.

As for the serpent and how Satan has turned himself into a huge serpent to tempt Adam and Eve, there is no evidence in the Quran and Sunna to prove that Satan comes to them in the form of a serpent or has a sexual relationship with Eve (Aisha Stacey, 2008). Nevertheless, the Prophet Mohamed urges to kill serpents except those live in houses until they are warned three times for the possibility that they are Jinn, "Abdullah narrated: While we were with Allah's Messenger (-) in a cave, Surat "Wal Mursalat" was revealed to him and we received it directly 
from his mouth as soon as he had received the revelation. Suddenly a snake came out and Allah's Messenger ( it!" We ran to kill it but it outstripped us. Allah's Apostle said, "It has escaped your evil, as you too, have escaped its." (Al Bukhri, 2009: 456), also he says "Verily in these houses there live aged (snakes), so when you see one of them, make life hard for it for three days, and if it goes away (well and good), otherwise kill it for (in that case) it would be a nonbeliever"( Imam Muslim, 2007 :2236).

In Shakespeare's Macbeth, Lady Macbeth plays the role of evil woman (femme fatale) who tempts her husband and brings about his destruction.

From the beginning of her appearance in act 1 , scene 5, when she reads Macbeth's message about the witches' predictions, Lady Macbeth immediately confirms that only her words will lead Macbeth to work actively to acquire a royal position of power, "I may pour my spirits in thine ear" (1.5.24). Lady Macbeth appears more tempting than witches in pushing Macbeth aggressively to implement the witches' prophecy. She is considerably more sinister and has more determination and stability than her husband. So when Macbeth decides to abandon the killing plot, she reacts sharply to remind him of his ambition and hope, "Was the hope drunk,/ Wherein you dress'd yourself? Hath it slept since,/ And wakes it now, to look so green and pale."(1.7:35-37). Lady Macbeth urges Macbeth strongly to kill Duncan by all means at her disposal, that is why we see her sometimes, inciting his manhood by taunting "And live a coward in thine own esteem,/ Letting 'I dare not' wait upon 'I would.'/ Like the poor cat I' the adage?"(1.7. 42-44), and sometimes undermining effectively his sense of masculinity by repudiating her femininity, "I have given suck, and know/ How tender ${ }^{6} t$ is to love the babe that milks me;/ I would while it was smiling in my face,/ Have plucked my nipple from his boneless gums,/ And dashed the brains out, had I so sworn as you/ Have done to this"(1.7. 54-58). Here, Lady Macbeth invokes a horrible image about the closeness of the nursing mother to the sucking child and how she is willing to kill her own child to prove her cruelty and willingness.

Undoubtedly, Lady Macbeth plays more effective role than the three witches in tempting Macbeth. To describe her character, Wilson Knight says "she is not merely a woman of strong will: she is a woman possessed - possessed of evil passion" (2001:168) and about her speech, he says that it is "demonic in intensity and passion. It is inhuman -as though the woman were controlled by an evil something which masters her, mind and soul". (2001:168).

By pouring her alluring and satanic words into Macbeth's ear, Lady Macbeth stimulates her husband to fulfil her plot. Even when Macbeth loses his courage to return back to "smear/ The sleepy grooms"(2.2.48-49) with bloody daggers, Lady Macbeth scorns at his mental weakness and take the daggers by herself to "gild the faces of the grooms withal" (2.2.55).

Lady Macbeth's passion and her uncontrollable enthusiasm reveal a stark contrast between the evil of witches who urges Macbeth because of their love for harm and destruction, and the evil of Lady Macbeth who motivates him because of her passion and her strong principle of self- interest and the advancement of the family (Alfar, 2003:63). Lady Macbeth uses her verbal charm more than her physical beauty to stimulate her husband to commit a crime. She has her social and economic reasons to behave in a brutal way. To be a queen and to have more power and glory, she encourages her husband to kill the king (Klein, 1998:9). Although, Macbeth and Lady Macbeth are imaginary characters, the situation that they face is a very real human situation, and we interact with them so deeply "not because they are mistaken for realities, but because they bring realities to mind" (Johnson, 1962: 2400).

Being strongly tempted by satanic forces (three witches), his wife and his ambition, Macbeth finally takes his decision to kill Duncan 'I am settled and bend up / Each corporal agent to this terrible feat' (1.7.80-81), and to commit many other crimes to secure his throne. So Macbeth's instigation, as Wilson Knight says "--comes partly from within, partly from without" $(2001,139)$.

\section{THIRD AXIS: THE FEELING OF REMORSE AND THE PUNISHMENT OF GOD IN BOTH QURAN AND SHAKESPEARE'S MACBETH}

Adam is hardly ended up eating forbidden fruit when he feels that his heart is constricted, filled of pain, sadness and shame. At the moment that Adam and Eve disobey God, the surrounding atmosphere is changed, their eyes are opened to see their private parts of body. So, they take the leaves of a fig tree to cover their 
bodies. God addresses them "Did I not forbid you from that tree and tell you that Satan is to you a clear enemy?"(The Nobel Qur'an, 7: 22), they say: "Our Lord, we have wronged ourselves, and if You do not forgive us and have mercy upon us, we will surely be among the losers."(The Nobel Qur'an, 7:23). God orders all (Adam, Eve) and Satan) to ""Descend, being to one another enemies. And for you on the earth is a place of settlement and enjoyment for a time."(The Nobel Qur'an, 7:24).

God Almighty punishes Adam and Eve physically as well as psychologically through:

1-The scandal: God Almighty makes their own private parts visible to feel shame and to recognize the greatness of their sin.

2-First Disobedience: The mentioning of Adam's sin in Quran makes him to be known as the first mankind who disobeys God's command.

3-Expulsion from heaven: God punishes Adam and Eve by expelling them from Eden inhabiting them on earth to be their own settlement and their offspring until the Day of Judgment.

4-Differentiation between them: God Almighty sends them in two different parts of the earth, until they find each other on the Mount Arafat in Mecca.

Thus, God says "And let not those who disbelieve ever think that [because] We extend their time [of enjoyment] it is better for them. We only extend it for them so that they may increase in sin, and for them is a humiliating punishment." (The Nobel Qur'an, 3: 178). God grants the respite to a sinner to feel ashamed of himself and make amends. But instead, sinner often feels confident and blatantly commits more sins, such as Macbeth. Such person is warned in the following Qur'anic verse "And (as to) those who reject Our communications, We draw them near (to destruction) by degrees from whence they know not" (The Nobel Qur'an, 7: 182). Therefore, sinners should always feel remorse and ask for forgiveness to avoid God's punishment.

Adam and Eve repent (do tawba) and receive words from God to avoid His punishment. Yet, God accepts their repentance (), saying "Then Adam received from his Lord [some] words, and $\mathrm{He}$ accepted his repentance. Indeed, it is He who is the Accepting of repentance, the Merciful", "We said, "Go down from it, all of you. And when guidance comes to you from Me, whoever follows My guidance - there will be no fear concerning them, nor will they grieve" (The Nobel Qur'an, 2: 37-38).
Repentance represents an open gate of God's unlimited indulgence for His slaves. If it has been closed, no one would ever attained salvation. Repentance is the avenues of success, rest, and forgiveness, as God says in His verses "And turn to Allah in repentance, all of you, $\mathrm{O}$ believers, that you might succeed" (The Nobel Qur'an, 24: 31), "Indeed, Allah loves those who are constantly repentant and loves those who purify themselves."(The Nobel Qur'an, 2:222), and "And those who, when they commit an immorality or wrong themselves [by transgression], remember Allah and seek forgiveness for their sins - and who can forgive sins except Allah? - and [who] do not persist in what they have done while they know", "Those their reward is forgiveness from their Lord and gardens beneath which rivers flow [in Paradise], wherein they will abide eternally; and excellent is the reward of the [righteous] workers"( The Nobel Qur'an 3:135-136).

Undoubtedly, sin destroys human's soul just as poison destroys his body therefore, it is compulsory for sinner to look for God's forgiveness just as patient looks for treatment to save his life. Sinner should repent continuously after each sin, and if he does not, he will be immersed in more sins, (look at Macbeth who is immersed in sin after killing Duncan). For this, we must resort to God and His protection to be saved from the sin and evil forces. After committing the first murder, Macbeth feels that he has lost peace of mind because he has killed the peace, "Sleep no more!"-“ Glamis hath murder'd sleep, and therefore Cawdor/ Shall sleep no more, Macbeth shall sleep no more!"'(Shakespeare, 2, 2, 41-43), and "O! full of scorpions is my mind, dear wife"(Shakespeare, 3,2,36).

Macbeth and Lady Macbeth's guilt subsequently affects their mental and psychological stability as a kind of punishment from God. For example, when Macbeth kills the king, he hears two voices from the room, "One cried "God bless us!" and "Amen"----"I could not say "Amen"/ When they did say "God bless us!'(Shakespeare, 2.2.26,28-29). Macbeth's inability to say "Amen" illustrates his far from God, and his killing of sleep depicts his insomnia and his loss of comfort and a feeling of safety. Moreover, the series of crimes that he commits depicts that he becomes extremely paranoid. Macbeth does not repent and continue to kill many more innocent people until he has been killed by Macduff. Macbeth's far from God 
makes him an accessible prey to the evil forces, directing him as they please. His carelessness of the punishment of God leads him to be indulged in sin. As a kind of divine punishment, Macbeth has been killed while Lady Macbeth has lost her mind and then committed suicide.

Both stories teach us that the battle between Man and Satan is psychological battle within Mankind's mind, and satanic forces use false words and promises to tempt Mankind to destroy him. To defeat the evil forces, Mankind should resort to God and His protection (Kaosar, 2014: 32-34).

\section{FOURTH AXIS: A STUDY OF THE NATURE OF SOME ENCOUNTERS WITH GOOD AND EVIL FORCES}

Adam, who symbolizes Mankind encounters Satan for several years, but he fails temporarily to overcome satanic temptation because of his human weakness (the tendency towards immortality in heaven) which has been exploited by Satan to cause his expulsion. Like Adam, Shakespeare's Macbeth fails to overcome the witches' temptation because of his human weakness (the ambition towards the throne). Temptation begins with the two (Adam and Macbeth) psychologically through a futuristic prophecy of satanic forces. Adam is prophesized to live eternally in paradise, while Macbeth is prophesized to be the next king. Then, the encounter begins to be external with both through (the wife, the ambition towards the greatness).

Actually, the moment of psychological weakness in mankind is a crucial moment between the humanity and the evil in which evil forces try to use it to conquer humanity and achieve its malicious goal. Adam and Macbeth both suffer this psychological struggle and fall because of their inability to overcome their tendencies unaware the dire consequences that will follow.

Adam, for example does not realize the hellish consequences of his wrong deed, but as soon as he does, Adam feels pain, regret, sadness, shame and tightness in his chest. $\mathrm{He}$ begs Gods to forgive him as soon as the surrounding atmosphere has been changed.

Just as moral weakness is a feature of humankind, the repentance is also a feature of humankind. Therefore, when Adam repents, God accepts his repentance since $\mathrm{He}$ knows that Adam does not disobey Him deliberately. But, if a humankind takes the side of evil, abandoning the side of humanity, he will be doomed, just as it happens to Macbeth.

Expectedly, Macbeth's situation is different from that of Adam, because he takes the side of evil abandoning his humanity. Macbeth never tries to repent and return back to his humanity, instead he continues his evil crimes with more determination until he becomes part of demonic forces. Macbeth's series of crimes widens the gap with his humanity. He becomes completely despair, believing that there is no return from his dreadful journey, "I am in blood/ Steeped in so far that should I wade no more,/ Returning were as tedious as go o're" $(3,4,137-139)$. As events progress, Macbeth becomes more horrendous. $\mathrm{He}$ losses his humanity and his spiritual principles, he goes to witches for advice, but he looks for it in a wrong place, and instead of saving him, they immerse him in the abyss.

About Macbeth's downfall, Bloom says that "Shakespeare rather dreadfully sees to it that we are Macbeth;..." $(1999,517)$, and "the dreadful is about to happen, and that we have no choice but to participate in it" $(1999,535)$. But Macbeth is no more than partial representation of humanity. He only represents mankind's weakness and his inability to confront evil. Therefore, we notice that Macbeth faces an evil temptation as a human being, sinning as a human being, but not repenting as a human being must do to overcome the evil forces. Macbeth is not an ordinary hard-hearted criminal. He has ethical soul and moral human impulse which show some strength against evil forces (witches' prophecy, his wife's words, his personal ambition toward power) at the beginning of the play, but not for a long time since his ethical soul is not strong enough to eliminate the inner and outer evil that constantly chase him. (Safiur Rahman, 2014. P. 15-18).

\section{FIFTH AXIS. THE TYPES OF HUMAN SOULS (NAFS) IN QURAN}

It has been difficult for scientists and researchers in the field of human psychology to be familiar with the study of the soul (Nafs), its components and mysteries, not because of the lack of information, but because of its complexity and contradiction.

Literally, the soul (Nafs) is defined as "the ego or the self, the ego-self, natural self, carnal self", identified "by the following appetitive qualities: pride (takabbur), greed (hirs), envy 
(hasad), lust (shahwah), backbiting (gheebah), stinginess (bokhl), and malice (keena)" (Bragazzi \& etal, 2018:2).

In Quran, the word (Nafs) is mentioned in collective (verse 4:1) and individualistic senses (verse 2:48), it has many qualities according to the actions of the owner, God says "So as for he who transgressed/ And preferred the life of the world,/ Then indeed, Hellfire will be [his] refuge./ But as for he who feared the position of his Lord and prevented the soul from [unlawful] inclination, Then indeed, Paradise will be [his] refuge.(The Nobel Quran,79:37-41). So, soul (Nafs) leads a man who satisfies its lust to his ruin, while a man who overcomes it preventing it from inclination will be in safe (Kaosar, 2014:59).

In the same vein, Ibn Katheer says in his book The Beginning and The End that "the $\mathrm{Mu}$ "'min are a people who have been prevented through the Qur'an from indulging in the pleasures of this world; it comes between them and what might destroy them. The Muemin is like a prisoner in this world, who tries to free himself from its shackles and chains, placing his trust in nothing in it, until the day he meets his Creator. He knows full well that he is accountable for everything that he hears, sees and says, and for everything that he does with his body" $(1990,276)$.

Unanimously, Muslim scholars (Al Ulama) agree that God has described at least three main types of the human soul in Quran, which are ranked from worse to better: Nafs al-Ammara Bissu "(the soul that urges evil), Nafs alLawwama (the reproaching soul) and Nafs alMutma inna (the reassuring soul). To identify the soul, God says "Indeed, the soul is a persistent enjoiner of evil, except those upon which my Lord has mercy. Indeed, my Lord is Forgiving and Merciful."(The Nobel Quran, 12:53), "And I swear by the reproaching soul [to the certainty of resurrection]" (The Nobel Quran, 75:2), "O reassured soul, /Return to your Lord, well-pleased and pleasing [to Him], /And enter among My [righteous] servants/And enter My Paradise."(The Nobel Quran, 89:27-30).

\section{1-Nafs Al-Ammara Bissu (The Soul That Urges Evil):}

Ibn Tabari interprets "Nafs al-Ammara Bissu" as a soul that invites its owner to do what it naturally desires, even if it is not in the satisfaction of God. It is identified by earthly desires and erotic qualities; such as greed, pride, envy, gluttony, lust, stinginess, backbiting that leads its owner to the ruin and punishment, and no one can get rid of its evil except those who turn to God.

According to Ibn Tabari's interpretation, evil lies in the soul (Nafs) and leads its owner to do the wrong. So if a mankind succumbs to its evil, he will be perished, but if he turns to God he will be survived. Hence, it is worthy to mention that no one can get rid of its evil without the divine salvation, as God says in Surah Yusuf "Indeed, the soul is a persistent enjoiner of evil, except those upon which my Lord has mercy. Indeed, my Lord is Forgiving and Merciful."(The Nobel Quran, 12:53).

As for the Prophet Adam, he does not disobey God deliberately, but he believes Satan's words when "he swore [by Allah] to them, "Indeed, I am to you from among the sincere advisors"(The Nobel Quran,7:21), since it does not come to Adam's mind that there is anyone who dares to swear by God falsely, so when Satan swears by God, Adam believes him and obeys.

But we must note here, that there is a difference between those who disobey God deliberately and those who disobey Him unintentionally. Adam disobeys God not because his soul urges him, but because he believes Satan's swear.

Macbeth, like Adam experiences external as well as internal encounter between good and evil. Macbeth consciously responds to the call of his evil soul (nafs al-ammara) which sow its seeds of evil within Macbeth when he commands the:

Stars, hide your fires!

Let not light see my black and deep desires;

The eye wink at the hand, yet let that be,

Which the eye fears, when it is done, to see (Shakespeare, 1, 4, 48-53).

Macbeth who represents an example of those who follow their evil souls, never feels remorse for killing King Duncan. On the contrary, he takes the side of evil deliberately and continues to kill more and more innocent persons to secure his throne. After he kills Duncan, Macbeth thinks that he "[has] scotched the snake, not killed it"( Shakespeare,3, 2, 13). Therefore, he decides to kill his close friend Banquo, and then Macduff's family by pursuing some murderers to do that. Macbeth's evil soul (nafs al-ammara) becomes able to control and turns him from a loyal general, defending his country from enemies to a traitor. 
2-Nafs Al-Lawwama (The Reproaching Soul):

God refers to this soul in surah Al-Qiyamah, "And I swear by the reproaching soul [to the certainty of resurrection]" (The Nobel Quran,75:2). This soul represents the human conscience that reprimands its owner for doing evil action. Abi 'l-Ḥasan al-Bașrī says, "You always see the believer blaming himself and saying things like, Did I want this? Why did I do that? Was this better than that? (Kaosar, 2014, $60)$.

About the reproaching soul, Ibn al-Qayyim says that it is "the one, which cannot rest in any one state. It often changes, remembers and forgets, submits and evades, loves and hates, rejoices and become sad, accepts and rejects, obeys and rebels", and it "blames itself on the Day of Judgement- for every one blames himself for his actions, either his bad deeds, if he was one who had many wrong actions, or for his shortcomings, if he was one who did good deeds. All of this is accurate"( 2014: 308).

After his disobedience, Adam regrets deeply and his reproaching soul blames him for his sin. He cries and pleads God Almighty to forgive him, so God accepts his repentance and forgives him.

While Macbeth's greatest sin is his total disregard for divine punishment. Macbeth neither fears the unseen retribution nor the idea of being punished. He lives blissfully in a world of satanic delusions and material comforts unaware that he is fettered down by his sins. Macbeth's disregard of God's punishment does not merit pardon. He never responds the call of his reproaching soul which reprimands him mentally by showing him some terrifying visions; such as bloody dagger, voice of two men, and bloody ghost of Banquo).

\section{3- Nafs Al- Mutma'Inna (The Reassured Soul):}

A reassured soul is defined as one of the degrees of human soul, it is superior type of the human soul. God refers to this soul in his verse "[To the righteous it will be said], "O reassured soul, Return to your Lord, well-pleased and pleasing [to Him], And enter among My [righteous] servants And enter My Paradise."(The Nobel Quran, 89:27-30).

This soul is satisfied with what God Almighty is pleased with, Ibn Abbas says, "It is the tranquil and believing soul." Al-Qatadah says, "It is the soul of the believer, made calm by what Allah has promised. Its owner is at rest and content with his knowledge of Allah's Names and Attributes, and with what $\mathrm{He}$ has said about Himself and His Messenger, and with what $\mathrm{He}$ has said about what awaits the soul after death: about the departure of the soul, the life in the Barzakh, and the events of the Day of Qiyamah which will follow. So much so that a believer such as this can almost see them with his own eyes. So he submits to the will of Allah and surrenders to Him contentedly, never dissatisfied or complaining, and with his faith never wavering. He does not rejoice at his gains, nor do his afflictions make him despair - for he knows that they were decreed long before they happened to him, even before he was created" (Al-Tabari, 1994:1323).

Imam Baghawi says, "The Nafs alMutma inna has an angel to help it, who assists and guides it. The angel casts good into the Nafs so that it desires what is good and is aware of the excellence of good actions. The angel also keeps the self away from wrong action and shows it the ugliness of bad deeds. All in all, whatever is for Allah and by him, always comes from the Soul which is at Peace. The Nafs al-Ammara Bissue has Shaytan as its ally. He promises it great rewards and gains, but casts falsehood into it. $\mathrm{He}$ invites it and entices the soul to do evil. He leads it on with hope after hope and presents falsehood to the soul in a form that it will accept and admire." (Al-Tabari, 1994:1323).

Adam's soul transfers from the stage of blame and remorse to the stage of reassured soul after he feels regret and begs God to forgive him. In this stage, Adam receives some words from God to repent and God forgives him.

Repentance is one way of God's indefinite indulgence with His servants, which has always been opened for His servants to reach salvation. Repentance not only removes the darkness of the sins from the heart, but also purifies it.

For Macbeth, the only active type of his soul is that urges evil. Macbeth's soul is prone to evil because his humanity cannot triumph over evil without grace of God, and Macbeth never resorts to God to help him.

\section{CONCLUSION}

In this comparing study, we conclude that Mankind cannot avoid or encounter satanic temptation without resorting to God's protection. Evil temptation is a frequent phenomenon in human life, it is not a sin in itself, but drifting behind it is a sin. Evil forces take various forms and use different means to tempt mankind. In Quran, the Creator shows us all kinds of subtle 
tricks and crafty methods used by satanic forces to tempt mankind who is too weak to encounter them without divine protection. Therefore, God teaches us in Quran how to deal with them to win the battle.

Evil forces are supernatural, invisible and vicious forces. They use subtle, various and evil ways to tempt mankind in which only one protective safeguard is not enough to face them, rather multi-dimensional safeguard is required. No matter how vulnerable human beings may be against the temptation of evil forces, since God Almighty reveals the nature and identity of the enemy, asking mankind to seek His refuge to be in safe. According to Quranic perspective, the evil forces can be emanated from supernatural forces, a person, or the inner self of man.

In case of Adam, evil forces take three forms, Satan who presents himself in a form of adviser and his false prophecy of eternal life, Eve who plays the role of temptress, and Adam's inner desire to live eternally in paradise.

Macbeth, like Adam faces three forms of evil forces which are the three witches and their prophecy of power and kingdom, the instigation of Lady Macbeth who represents evil force in human form, and Macbeth's ambition that represents his own evil inner self.

As Adam encounters the conflict between good and evil, Macbeth also encounters such a battle. But in case of Adam, he never insists on evil deed, and when he realizes his sin, he immediately regrets and asks God's forgiveness. But unaware that his strength is insufficient to confront the various evil forces, Macbeth tries to hover over evil and examine it without divine help, therefore, he fails to encounter them. So, Shakespeare's Macbeth does not represent humankind as a whole. He only represents earthly part of mankind, the part which is made of clay, but not the spiritual part which is brought from God (His soul). Macbeth represents only the weakness of human being and his vulnerability to encounter evil forces. While Adam represents the humanity as a whole, since he shows us both, his weakness to face Satan and then his pure spirituality to retort to God.

\section{REFRENCES}

Al Bukhri, Muhammad Ibn Ismaeel (2009). The Translation of the Meaning of Sahih Bukhari. Translated by M. Muhsin KhanMika'il. Edited by: Mika'il al-Almany. Saudi Arabia: Riyadh, Darussalam, Book 60, Vol 6.
Alfar, Cristina León (2003). Fantasies of Female Evil: The Dynamics of Gender and Power in Shakespearean Tragedy. New York: University of Delaware Press.

Al-Tabari, Muhammad ibn Jarir (1994). Tafsir alTabari: Jami' al-Bayan fi Tafsir al-Qur'an, 226). Vol. 13, Bulaq.

Bloom, Harold (1999). Shakespeare the Invention of the Human. Fourth Estate Limited, London.

Branham, William (2005). The Original Sin. Available https://www.williambranham.com/theoriginal-sin/. Retrieved November 22, 2018.

Howard, E. Jean (2003). Macbeth, (introductory essay), collected in The Complete Works of Shakespeare, 5th Edition, and Edited by David Bevington, New York: Longman.

Ibn al-Qayyim, Shams al-Din Muhammad bin Abi Bakr (2014). Madarij as-Salikin fi Manazili Iyyaka Na'budu wa Iyyaka Nasta'in. Vol. 1. Dar-ul Hadith, Egypt, Cairo.

Ibin Katheer, Ismail bin Omar (1990). The Beginning and The End. Lebanon: Beirut. Al-Ma'araf Library. vol. 9, Egypt, Cairo

Imam Abu Abdur Rahman, Hafiz \& Ahmad bin Shu'aib bin 'Ali An-Nasai'(2007). English Translation of Sunan An-Nasa'i. Vol. 4, KSA: Riyadh, Maktaba Dar-us-Salam.

Imam Muhammad at-Tirmidhi, Abu 'Isa (1978). Jami at-Tirmidhi: Chapters on Tafsir. Vol. 5, Book 44, Hadith 2955. Available at https://sunnah.com/urn/639390. Retrieved October 18, 2018.

Imam Muslim, Abui Hussain Ibn al-Hajjaj (2007). English Translation of Sahih Muslim. Vol. 1, KSA: Riyadh, Maktaba Dar-us-Salam.

Jack, Jane (1955). "MacBeth, King James, and the Bible.". The Johns Hopkins University Press. Retrieved 9 August 2018.

James I, King of England (1597). Daemonologie [electronic Resource]: In Forme of a Dialogue, Diuided into Three Bookes. Edinburgh: Printed by Robert Walde-graue, Printer to the

Kings Majestie. Early English Books Online. Retrieved 20 August 2018.

Johnson, Samuel (1962). The Preface to Shakespeare. The Norton Anthology of English Literature. Vol.1, Seventh Edition. Ed. Abrams M. H. USA: W.W. Norton and Company Inc. 
Kaosar, Mohammad Ahmed (2014).__ Islamic Discourse in Shakespearean Study: Teaching Shakespeare from Islamic Perspective Worksheet on Macbeth. International Islamic University Chittagong, Bangladesh.

Klein, Joan Larsen (1998). Lady Macbeth: Infirm of Purpose." Shakespeare: Macbeth. New York: Signet.

Knight, Wilson (2001). The Wheel of Fire, Routledge Classics, London.

Lings, Martin (1998). The Sacred Art of Shakespeare, To Take Upon Us the Mystery of Things. Rochester: Inner Tradition International.

Mohammed Saleh Al-Managed(2019). "The story of Adam, peace be upon him, entering and leaving Paradise". Available at https://almunajjid.com/courses/lessons/139. Retrieved 20 October 2018.

Muhammad Safiur Rahman(2014). Humanity's Encounter with the Powers of Darkness ${ }^{\text {, }}$ : A Study of Shakespeare's Macbeth from the Quranic Point of View. Journal of Education and Practice. Vol.5, No.39. Bangladesh, Chittagong.

The Noble Quran (2016). Available at https://quran.com/?local=en. Acessed October $18,2018$.

Thomas, Keith(1971). Religion and the Decline of Magic. Charles Scribner's Sons, USA: New York.

Shakespeare, William (1958). Macbeth. Bernard Lott (ed). London: Longmans, Green and Co., Ltd

Stacey, Aisha (2008). The Religion of Islam: The Story of Adam (Part 1 of 5): The First Man. Available at https://www.islamreligion.com/articles/1190/v iewall/story-of-adam/. Retrieved October 25, 2018. 


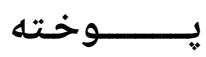

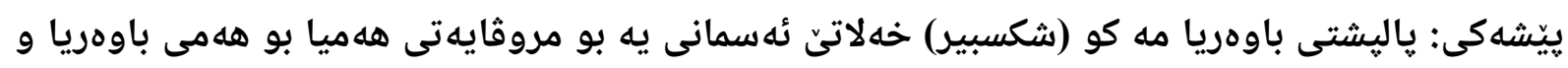

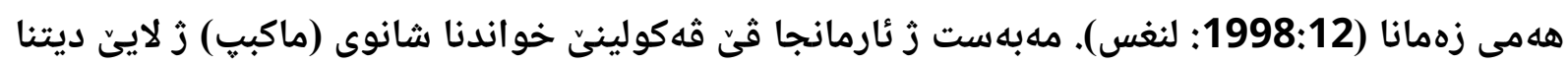

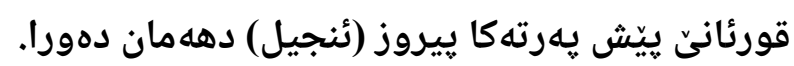

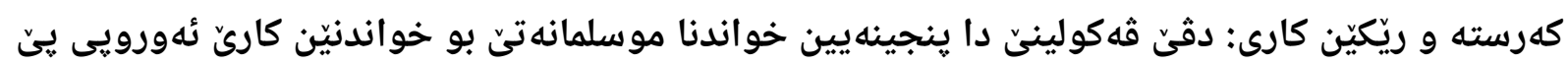

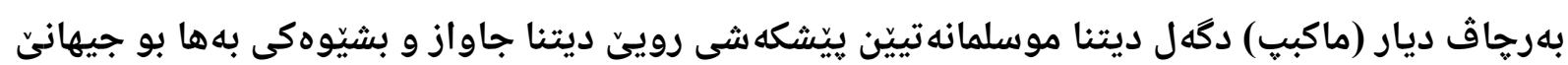
ب ديتنا ئهورويى. ئهنجام: هه ماههنغيا فيّ قه كولينى دشلوقه كرنا ده قى ئه ياتيّن قورئانا بيروز دكه ل فرمودين بى غه مبه رى

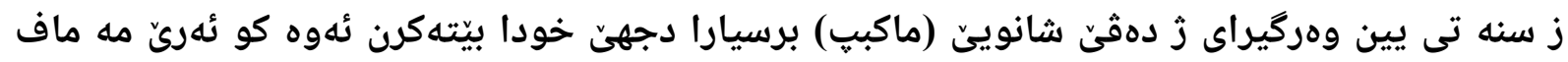

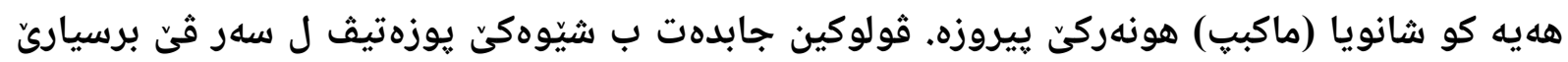

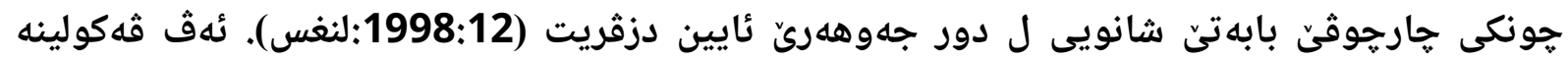

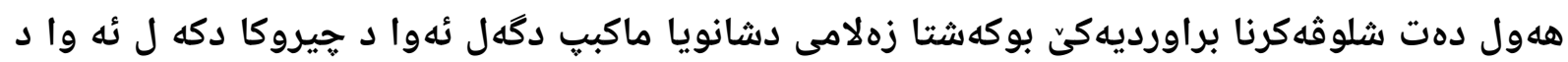

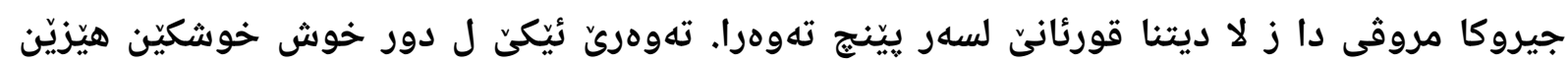

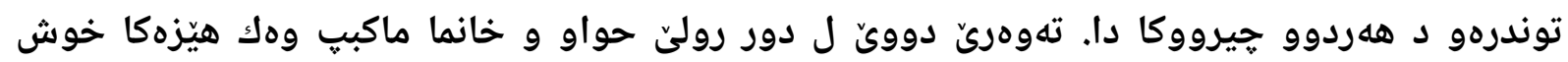

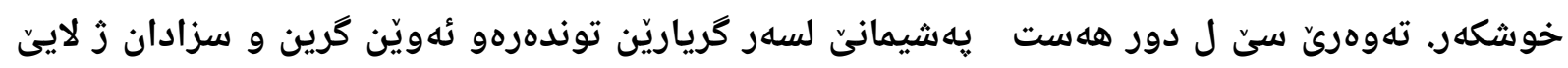

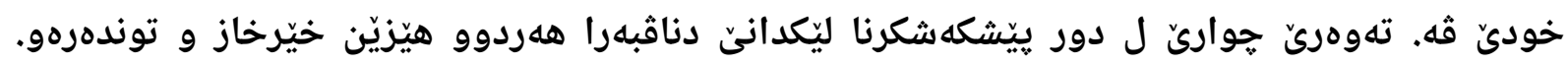

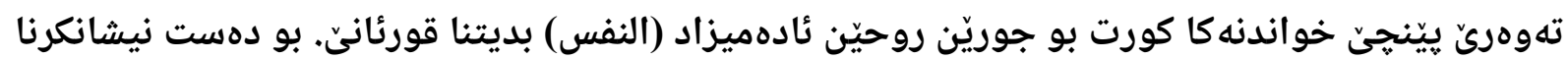

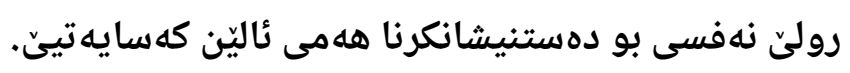

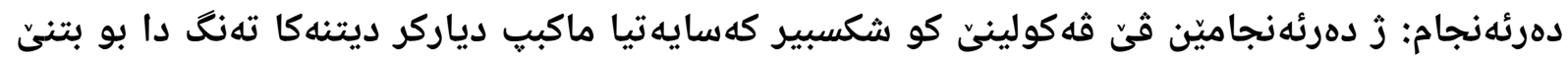

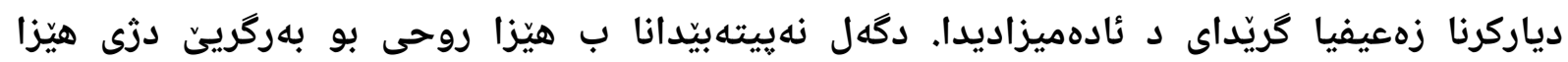

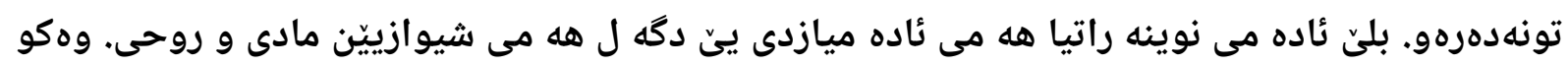

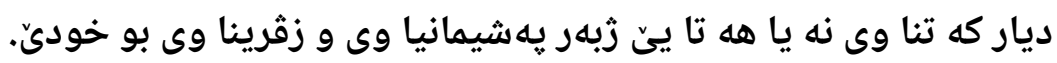

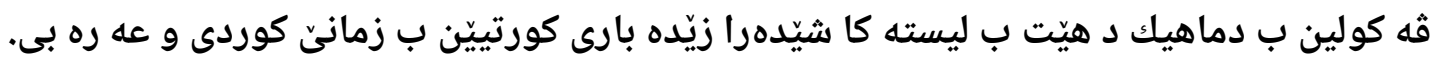


الخلاصة

اندفاعا من قناعتنا بأن "شكسبير هو هبة السماء للبشرية جمعاء ، لكل عقيدة ، ولكل عصر" (12:

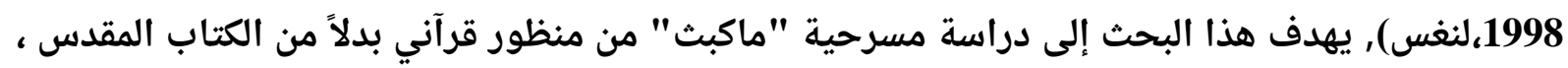

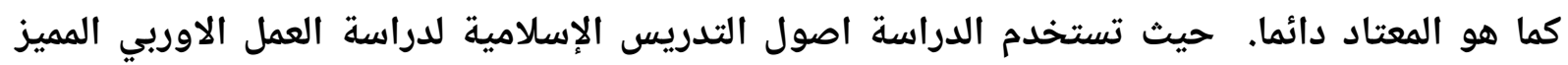
"ماكبث" ، مع افتراض أن الإسلام يقدم وجهة نظر مختلفة وبشكل فريد عن العالم عن المنظور الأوروبي.

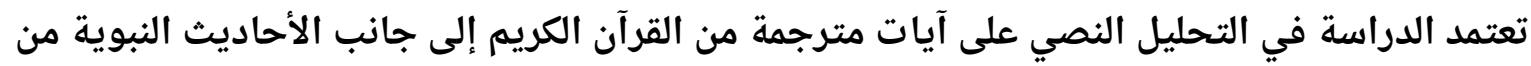

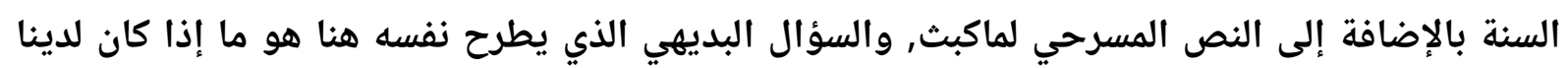
الحق في تصنيف مسرحية ماكبث الى انه "فن مقدس", تجيب الدراسة وبشكل إيجابي على هذا السؤال

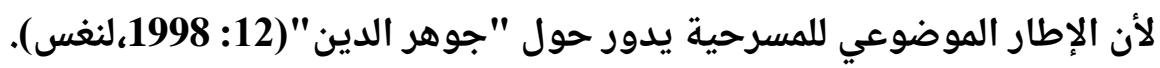
تحاول الدراسة تحليل ومقارنة سقوط الرجل في مسرحية ماكبث مع تلك التي في قصة خلق الإنسان من منظور قراني على خمس محاور. المحور الأول يدور حول إغراءات القوى الشريرة في كلتا القصتين.

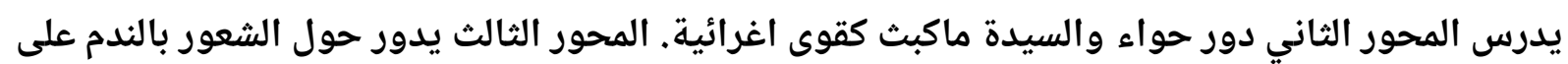

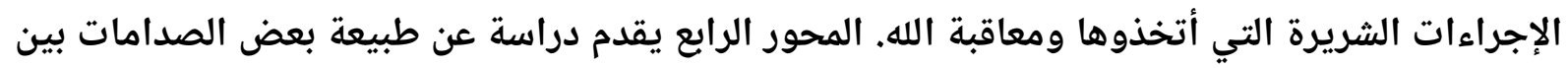
قوى الخير والشر. يقدم المحور الخامس دراسة موجزة لأنواع الروح البشرية (النفس) من منظور قراني لتشخيص دور النفس في تحديد معالم كل شخصية. استنتجت الدراسة الى أن شكسبير قدم شخصية ماكبث من منظور ضيد معال كيق ليمثل فقط الضعف المتأصل

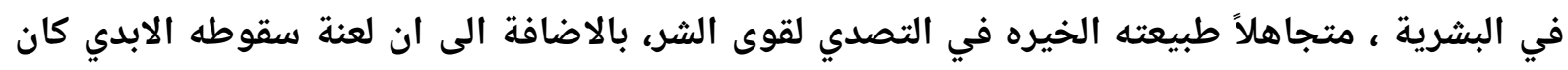

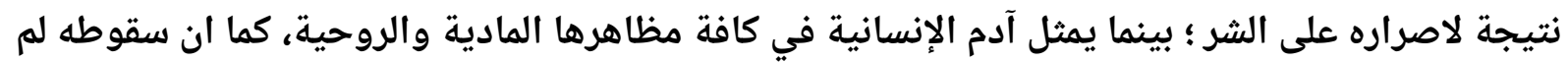

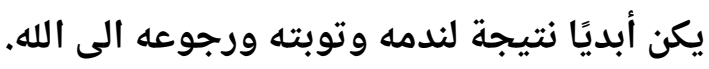
تنتهي الدراسة بقائمة من المراجع بالإضافة إلى الخلاصة باللغتين الكوردية والعوبه العربية. 